\title{
COGNITION OF THE PERINATAL SYMBOLISM \\ THROUGH VISUALISED REPRESENTATION \\ OF A PROSPECTIVE PSYCHOLOGIST
}

\section{ПІЗНАННЯ ПЕРИНАТАЛЬНОЇ СИМВОЛІКИ \\ ШЛЯХОМ АНАЛІЗУ ВІЗУАЛІЗОВАНОЇ РЕПРЕЗЕНТАЦЇ̈ МАЙБУТНЬОГО ПСИХОЛОГА}

\section{Yuliia Sidenko ${ }^{1}$ \\ Oleksandra Franchuk ${ }^{2}$}

DOI: https://doi.org/10.30525/978-9934-588-15-0-127

Abstract. The article is devoted to the research into the vital theoretical and methodological issues pertaining to seeking ways of depth cognition of the psychological meaning of perinatal symbolism, which can be objectified through the means of representation by prospective psychologists during the group psycho-correction sessions of Active Socio-Psychological Cognition (ASPC). The study has been conducted in accordance with the psychodynamic paradigm, which in its turn synthesises psychoanalytic, phenomenological, humanistic and other approaches to the cognition of an individual's psyche. The elucidation of the quantitative data confirms that the diagnostic and correction process in ASPC groups opens the opportunity for self-development to an individual, makes it possible to recognise the psyche's semantic features provoking conflicts, with special attention drawn to those generated by the fixations of the perinatal period. Subsequently, it becomes attainable to reconstruct the corresponding energy towards the progressive vector. The article draws attention to the fact of the involuntary activity of perinatal factors "begging to the surface", rising above the story-themed meanings of reproductions intended by the authors. That is, the perinatal symbolism is archetypal by its nature, which, a priori, places an intentionally emotive orientation (energy boost) with the cognitive subordination.

\footnotetext{
${ }^{1}$ Candidate of Psychology Sciences, Lecturer in Applied Psychology, Cherkasy Bohdan Khmelnytsky National University, Ukraine

${ }^{2}$ Candidate of Psychology Sciences, Lecturer in Applied Psychology, Cherkasy Bohdan Khmelnytsky National University, Ukraine
} 
The perinatal problems of an individual manifest themselves in contradictory tendencies: those striving objectification and, at the same time, those driving to a mystery creation, that signify the presence of the oedipal component, the cognition of which requires psychoanalysis conducted through a multi-level gradually progressive process of diagnostics combined with correction. The paper has shown the experimental significance of visualised representation of the psyche of prospective psychologists through the cognition of perinatal symbolism. It is catalysed by the trace effects of the psyche and childhood fixations of the pre-linguistic period of development that destroy the personality's prerequisites for a psychologist's professional development; influence of perinatal trace fixations on life and personal parameters of professional growth of a practical psychologist. The article argues that the perinatal period plays a significant role in the emergence of the destruction of the individual's behaviour that is extremely undesirable for a prospective psychologist, whose professional responsibilities include an adequate reflection of the "here and now" situation, which determines the effectiveness of the interaction with another person. During the ASPC sessions, prospective psychologists are equipped with the tools for personal growth, prospects for self-development. Moreover, they become aware of the psyche not merely in theory, but also in practice, through their own reflexive experiences of deep introspection revealing the possibilities for a personal and professional renewal.

\section{1. Ветуп}

Статтю присвячено висвітленню важливої теоретико-методологічної проблеми - пошуку шляхів глибинного пізнання психологічного змісту перинатальної символіки, опредметненої у засобах репрезентації майбутніх психологів. Феномен перинатальної символіки, візуалізованої майбутнім психологом, розглядається як важливий інструмент дослідження його особистісних проблем. Процес репрезентації особистістю візуалізованими засобами є достовірною одиницею наукового аналізу психіки, як такої, що «себе-в-самій-собі ілюструє» шляхом опредметнення ідеальних реальностей. Візуалізація розуміється як кінцевий підсумок, результат внутрішньої процесуальності, опредметнено представленої завдяки перекодуванню смислових параметрів глибинних чинників («візуальних кодів»). Мета даної наукової роботи 
полягає у розкритті значення візуалізованої репрезентації у пізнанні глибинних чинників перинатального періоду розвитку суб'єкта. Стаття виконана у психодинамічній парадигмі, що синтезує психоаналітичний, феноменологічний, гуманістичний та інші підходи до пізнання психіки. У основу концепції дослідження покладено психодинамічну парадигму, розроблену академіком НАПН України Т. Яценко, що базується на: розумінні цілісності психіки в їі свідомих і несвідомих виявах; суперечливій сутності психічного, породжуваної базальним конфліктом «життя-смерть»; спонтанній активності суб'єкта; контекстності та опосередкованості глибинного пізнання психіки.

\section{2. Представленість поняття «репрезентація» у філософії}

Тема статті потребує розгляду поняття «репрезентація», яке є міждисциплінарним та торкається різноманітних сфер наукового знання, зокрема: філософії та психології. Репрезентація у філософському розумінні полягає у представленні одного за допомогою іншого та $€$ функцією знаку (створює знак і з'являється як знаковий феномен). Також це поняття співвідноситься зі значенням «відображення», або образного представлення.

Вивчення форм репрезентації представлені у феноменології Е. Гуссерля, зокрема у роботі «Ідеї до чистої феноменології та феноменологічної філософії» (1900), де він розмежовує репрезентацію - «представництва» на те, що споглядається одинично і загально понятійно. У другому випадку, як зауважує Е. Гуссерль, репрезентація відсутня. Філософ наголошував на помилковості твердження про те, що репрезентація - це лише психологічна функція і вказував, що репрезентативна функція виявляє свою своєрідність феноменально. Е. Гуссерль відмічає важливі для розуміння природи репрезентації положення диференціацію типології «представництва» та відмінність знака, як посередника і знаку у його семіотичній функції. Дж. Берклі аналізуючи аспекти репрезентації, поєднує знак, як репрезентант для кожного одиничного, що входить в поняття смислу і знаку, що має значення.

Теорія репрезентації, як невід'ємної складової теорії пізнання належить Е. Кассіреру, який розглядав іiі не лише як операцію пізнання, але і як фундаментальне поняття філософії символічних форм. Він відмічає, що центральне систематичне значення, це поняття набуває 
у Платона, а пізніше у філософії Г. Лейбніца та Хр. Вольфа, де репрезентації надається особливе значення як єдиної діяльнісної основи сили, проявами якої є різні здібності душі. Е. Кассірер визначав репрезентацію як - представлення одного елемента свідомості в іншому i за допомогою іншого, коли думка не прямолінійно застосовується до дійсності, пропонуючи систему знаків і використовує «представників предметів. Розробляючи теорію пізнання, у контексті філософії символічних форм, Е. Кассірер виявив зміст операції репрезентації - вихід за межі досвіду у трансцендентальну сферу знання, що визначається суспільством та культурою.

Концепція репрезентації філософа М. Вартофского, визначає іï як особливі артефакти, що створюються з метою збереження і передачі навичок та умінь у виробництві і використанні «первинних» артефактів (знарядь праці, форм соціальної організації). Такі репрезентації включають жести, мову, музику. М. Вартофский пише, що репрезентація з'являється як специфічно людський спосіб пізнання. Без неї немає людського знання. У книзі «Репрезентація і наукове розуміння» (1963) автор відмічає, що важливо розрізняти зовнішню репрезентацію, вираження деякого змісту в зовнішній формі, яка є передумовою для так званої внутрішньої репрезентації, тобто діяльності рефлексії (мислення, уява), що є розвитком здатності людського пізнання.

У філософії Н. Гудмена проблема репрезентації пов'язана з дослідженням «вербальних» (чи «лінгвістичних») або «невербальних» форм. Виступаючи проти розділення репрезентації на «дане» $\mathrm{i}$ «конвенціональне» філософ визначав будь-яку репрезентацію як символ, розробивши загальну теорію символів.

\section{3. Поняття «репрезентація» у психології}

В психології термін «репрезентація» використовується у віковій психології (і означає символічне відображення того, як суб'єкт відчуває і презентує себе з позиції власного гендеру); у психодіагностиці існує поняття - репрезентативна система (за допомогою якої людина отримує інформацію з навколишнього світу, в ньому орієнтується, відображає своє відношення до всього, що відбувається в думках, почуттях, вчинках). В розділі психології, присвяченому фізичному i когнітивному розвитку у ранньому дитинстві зазначається, що основ- 
ною характерною рисою дворічних дітей (на відміну від немовлят) $є$ символічна репрезентація - використання дій, образів, слів для представлення власних переживань чи подій. Виділяється декілька аспектів символічної репрезентації: здатність використати числа для представлення кількості об'єктів у впорядкованому ряді; набуття навичок образотворчої діяльності. З'являючись приблизно в два роки, репрезентація розвивається далі (дитина в чотири роки краще користується символами). Когнітивна психологія, початковим етапом утворення репрезентації, визначає перцептивну інформацію. Такі психічні явища, як відчуття, думки, почуття, переживання, уявні образи не можуть спостерігатися іншими людьми безпосередньо. Тому, репрезентація має особистісний характер (персоніфікований).

Репрезентація у психоаналізі описана 3. Фрейдом, який вказував на те, що репрезентація, первинно $є$ кінестетичною, відноситься до емоційно-чуттєвої сфери, але при цьому вона обов'язково повинна «взаємодіяти» із зоровою, а потім - із вербальною репрезентаційними системами (щоб «описати цю подію», «висловити афект»). При цьому пережита подія позначалася словесно та отримувала вербальне вираження. Фактично, 3. Фрейд розрізняє в психічній репрезентації два елементи - представлення і афект, і вказує на їх відмінність: лише перший елемент (представлення як репрезентатор) може без будь-яких змін увійти до системи несвідомого.

У наукових роботах Л. Хатчеон зазначає, що дослідження репрезентації стає не аналізом мнемічного відображення або суб'єктивної проекції, але вивченням того, яким чином наративи і образи структурують наше бачення самих себе і наших уявлень про себе, в сьогоденні і майбутньому.

Дж. Хол вказує, що репрезентація - це використання мови для створення усвідомленого висловлювання, невід'ємна частина процесу обміну значеннями між представниками культури. Дослідник пише: «Вона включає використання мови, знаків і візуальних образів, які заміщують собою, або репрезентують, речі» [6, с. 48]. Об'єкти репрезентації не мають сенсу автомно, вони виникають у процесі інтерпретації і комунікації, кодування і декодування текстів та залежить від культурного контексту. Вчений виділяє дві системи репрезентації:

1. «Ментальні репрезентації», тобто система понять про явища та різні способи їх групування, систематизації і співвідношення між 
собою. Вона складає своєрідну «концептуальну карту», що дозволяє людині інтерпретувати світ, що ії оточує. У рамках однієї культури індивідуальні карти подібні, що дозволяє іiї представникам вибудовувати схожі уявлення про навколишню дійсність.

2. Мову, тобто систему знаків, за допомогою якої ментальні репрезентації можуть бути виражені і включені в процес обміну між людьми. Таким чином, репрезентація - це процес створення значень у мові. Суть цього процесу полягає у взаємодії трьох складових: «речей», тобто об'єктів і процесів зовнішнього світу, понять, в яких зафіксовані уявлення про ці «речі», і мови, тобто знаків, в яких ці представлення виражаються.

\section{4. Теоретичний аналіз поняття візуальності}

Звернімося до поняття «візуальний» (від лат. visualis - зоровий), що у словниках має наступні означення: «метод представлення інформації у вигляді оптичного зображення (наприклад, у вигляді малюнків, фотографій, графіків, діаграм, структурних схем, таблиць, карт тощо)» [3, с. 47]; «це передача на пристрої відображення (дисплеї, графопобудовувачі тощо) об'єктів у реальних або умовних зорових образах. Прикладом реального образу може бути фотокартка, а умовного - діаграма; «виведення даних з метою забезпечення максимальної зручності розуміння їх користувачем, наприклад, результатів оброблення наукового експерименту (scientific visualization) [2, с. 36]; «подання фізичного явища або процесу в формі, яка є зручною для сприйняття» [4, с. 281].

Першим звернув увагу на зростаючу роль візуального у сучасному світі та відмітив вплив способів відтворення візуальних об'єктів на культуру суспільства, був німецький філософ В. Беньямін. У роботах дослідників Ф. Бартлетта та М. Мінського, феномен візуалізації тлумачать як винесення в процесі пізнавальної діяльності зі внутрішнього плану в зовнішній план мислеобразів, форма яких стихійно визначається механізмом асоціативної проекції. 3 вищезазначеним твердженням солідаризується А. Вербицький, який вважає процес візуалізації - це згортання розумового змісту в наочний образ; будучи сприйнятим, образ може бути розгорнутий і служити опорою адекватних розумових і практичних дій. Іншої думки О. Макарова, яка наголошує, що візуалізація - це спосіб фіксації і трансляції інформації, який не тільки доповнює, але й слугує альтернативою вербально-письмової комунікації. 
У сучасній науці поняттю «візуалізація» надають наступні визначення: представлення чого-небудь фізичного - процесу, явища і т. п. у формі, зручній для спостереження; методика спрямованого виклику образу.

Таким чином, феномен візуалізації розуміється, в першому випадку, як кінцевий підсумок деякої (тобто результат) процесуальності, представлений за допомогою візуальних кодів. У даному випадку візуалізація дозволяє відобразити розвиток дії, спостереження за якою в звичайних умовах ускладнене, або неможливе. Наприклад, відомий випадок, коли наприкінці XIX століття англійський фізик Дж. Томсон демонстрував колегам і учням кекс, щоб пояснити власну теорію будови атомного ядра. Тому науковий потенціал візуалізації був оцінений саме в технічних і природничих науках, коли в лабораторних умовах проводилася реконструкція процесів і явищ, які зустрічаються виключно у природі.

У другому випадку під візуалізацією розуміють процедуру, під час якої використовується спеціалізований апарат (кіно-, фотокамера, лазер та ін.) і набір прийомів (композиція, монтаж тощо). Мотив вибору тієї або іншої методики для представлення образу обумовлений технічним інструментарієм, який існує в конкретно-історичному проміжку часу, так само як і ідейним задумом автора.

Аналіз літератури дозволяє виділити декілька базових підходів до аналізу візуальності: психоаналітичний, соціально-критичний, деконструкціоністський, герменевтичний, семіотичний, структуралістський, дискурсивний.

Зупинимось коротко на вищевказаних підходах. Психоаналітична методологія у дослідженнях візуального, спочатку застосовувалась серед мистецтвознавців. Головним чином їх цікавило відображення особистісних травм, комплексів і пригнічених бажань авторів у їх твоpax. Зокрема, родоначальник психоаналізу 3. Фрейд захоплювався аналізом витворів мистецтва, зокрема живопису і скульптури. Присвячені цьому питанню стали дослідження особистості Леонардо да Вінчі і статуї Мікеланжело «Мойсей». 3. Фрейд пов'язував процес створення витворів мистецтв з фантазією і міфотворчістю, через які відбувається сублімація несвідомих прагнень, бажань. Він вважав, що в процесі творчості людина допомагає своїм природним потягам ужитися 3 «реальністю», витісняючи соціально неприйнятні імпульси. 
Важливий внесок психоаналізу в дослідження візуального полягає в уявленні про те, що несвідоме представлене у свідомості за допомогою образів. Одночасно психіка здатна сприймати образи ззовні і реагувати на них. Не даремно В. Беньямін вважав, що фото- і відеокамера відкривають нам область візуально-несвідомого, подібно до того як психоаналіз - інстинктивно-несвідомого.

Дослідники візуальних образів проектують методологію і терміни психоаналізу на об'єкти, що вивчаються, щоб розкрити певні феномени. Зокрема звертаються до використання метафор, які поєднують досліджувані образи 3 психоаналітичним інструментарієм. Мова кіно, як і мова сновидінь, наповнена образами, що володіють прихованими значеннями. К. Корбут відмічає, що деякі авангардні фільми зважаючи на відсутність чіткої сюжетної лінії і хаотичного відеоряду стають доступні розумінню, тільки якщо їх розглядати як сновидіння, з точки зору концептів згущення, зміщення, символізації, драматизації тощо.

Візуальна репрезентація об'єктивується за допомогою: самопрезентації, малюнків (психомалюнків), неавторських малюнків (репродукції художніх полотен), проективних методів, сновидінь, казок, у рекламній продукції, фільмах, архітектурних творах, предметних моделях, візуально-уявній репрезентації (проективні методики, катитимні переживання образів, кокологія).

\section{5. Основні підходи дослідження самопрезентації}

Представимо основні підходи до визначення поняття «самопрезентація»: «самопрезентація - це цілеспрямована діяльність по контролю за враженням», що справляється на інших [2, с. 398]; «це діяльність, яка відображає трансакцію між «Я» і аудиторією в особливому соціальному контексті і утворена комбінацією особистісних і ситуативних чинників» [3, с. 248]; «це процес формування ідентичності, яку одна людина презентує іншим людям, через зовнішні прояви» [4, с. 321]; «короткочасний, специфічно мотивований і організований процес пред'явлення інформації про себе у вербальній і невербальній поведінці» [5, с. 280]; «процес регуляції враження, що справляється суб'єктом, з урахуванням специфіки соціальної ситуації, і (чи) вираженням системи уявлень про самого себе» $[1$, с. 56$]$. 
Для подальшого розгляду феномену самопрезентації звернімося до невід'ємного поняття «проекція». Термін «проектні» був уперше використаний Л. Франком в 1939 р. для об'єднання вже відомих на той час методичних прийомів (таких, як асоціативний тест К. Юнга, тест Роршахата ін.). Як відомо, спочатку ці методики створювалися для клінічних цілей і у своїх класичних варіантах використовувалися головним чином в клініці неврозів. Словник дає наступне визначення: (лат. projectio - викидання вперед) - сукупність методик, спрямованих на дослідження особистості і розроблених у рамках проектного діагностичного підходу [2, с. 217].

Проектні методи діагностики характеризуються такими особливостями: проектними інструментами $є$ методики замаскованого тестування, коли обстежуваний не підозрює про тип психологічної інтерпретації, яка буде дана його відповідям; проектні методики характеризуються глобальним підходом до оцінки суб'єкта, увага фокусується на картині особи в цілому, а не на дослідженні окремих його рис; проектні методики вважаються особливо ефективними при виявленні прихованих, латентних або неусвідомлюваних сторін особи.

Перша класифікація проектних методів була запропонована Л. Франком. Але з часом, його класифікацію проектних методів доповнили та внесли корективи задля якнайповнішої характеристики проективної техніки:

1. Конститутивні. Суб'єкту пропонується який-небудь аморфний матеріал, якому він повинен надати сенс.

2. Конструктивні. Пропонуються оформлені деталі, з яких треба створити осмислене ціле і пояснити його.

3. Інтерпретативні. Необхідно представити, інтерпретувати яку-небудь подію, ситуацію.

4. Катартичні. Пропонується здійснити ігрову діяльність в особливо організованих умовах.

5. Рефрактивні. Індивідуальні особливості, приховані мотиви дослідник прагне діагностувати по тих мимовільних змінах, які вносяться у загальноприйняті засоби комунікації, наприклад, мова, почерк.

6. Експресивні. Здійснення особою образотворчої діяльності, малюнок на вільну або задану тему. 
7. Імпресивні. Ці методики грунтуються на вивченні результатів вибору стимулу з ряду запропонованих. Людина обирає стимули (тест Люшера), яким вона віддає перевагу.

8. Аддитивні. У цих методиках потрібно завершити початок пропозиції, розповіді або історії.

Особливе місце серед різноманіття проектних методів діагностики займають малюнкові методи. Малюнок дозволяє відображати в образах дійсність і проектувати зміст психіки в символи. Перевагою малюнку є здатність до об'єднання в образах і певних символах зовнішній і внутрішній світи, це дає можливість спостерігачеві (психологові) проникати у внутрішні характеристики психіки суб'єкта.

Малюнкові техніки, незалежно від їх відмінностей в плані дослідницьких завдань, об'єднані загальним методологічним підходом, мають ряд характерних рис: формальна інтерпретація, опис даних та ін. Окремі методики спрямовані на вивчення дискретних психологічних властивостей, як рівень інтелектуального розвитку, сформованість психічних новоутворень, характерологічні особливості індивіда, і т. д. У психотерапії використовується тематичне малювання з метою відображення людиною нав'язливих думок, страху, що має сприяти їх подоланню.

Термін «психомалюнок» набув змістового наповнення у рамках методу активного соціально-психологічного пізнання (АСПП), що розробляється в науковій школі Т. Яценко. Психомалюнком називають малюнок, в якому автор намагається цілеспрямовано передати психологічний зміст, визначений темою малюнка 3 метою подальшої рефлексії зображення в діалозі з психологом. Передбачається комплексний розгляд малюнків, хоча в окремих випадках робота може відбуватися і по одному малюнку. Існують відмінності у підходах до застосування малюнкових методик: тестовий і глибинно-психологічний. Цією провідною відмінністю визначаються можливості малюнкових методик цілісно пізнавати психіку суб'єкта. Проективні малюнки, як зазначає Т. Яценко, освітлюють лише «певну специфічну грань, але не структурну основу і логічну організацію внутрішньо психологічних феноменів» [10, с. 110]. Психоаналітична робота по застосуванню малюнка має ряд істотних відмінностей від використання проектних методик у класичному їх варіанті. 
Для отримання особистісно значимої інформації, яка торкається системної впорядкованості психіки, енергетичної направленості неусвідомлюваних тенденцій поведінки, важливо самостійно виконувати психомалюнки, відповідно до комплексу запропонованих тем. Процес психоаналітичної інтерпретації малюнків будується на діалогічній взаємодії психолога з їх автором, тому більшість деталей можна уточнити, розкрити, розшифрувати вербально. Сам процес виконання малюнків має психотерапевтичний ефект, завдяки вивільненню енергії у процесі малювання. Логіка психологічного змісту у малюнковій продукції виявляється у ході довготривалої аналітичної роботи через знаходження взаємозалежностей образів окремих малюнків та їх спільні характеристики. За цієї умови комплекс тематичних психомалюнків $\epsilon$ інформаційнішим аніж окремо взяті малюнки.

\section{6. Сновидіння, як вид візуалізованої репрезентації}

Розглянемо докладніше інший вид візуалізованої репрезентації сновидіння. Сучасні психологічні словники визначають сновидіння як «спонтанний, некерований, суб'єктивно пережитий потік уявлень, переважно зорової модальності»; «універсальне людське переживання» $[4$, с. 390].

Відома робота 3. Фрейда «Тлумачення сновидінь» поклала початок концепції про те, що в снах зашифровані витіснені імпульси і бажання у вигляді візуальних образів-символів. Згідно теорії психолога, інтерпретація цих образів може допомогти зрозуміти, що ж відбувається 3 людиною. 3. Фрейд називав сон «королівською дорогою» до несвідомого. Психоаналітик здійснив припущення, що сновидець на підсвідомому рівні вже знає значення свого сновидіння. I мета психоаналізу допомогти це знання відшукати і зрозуміти.

До психологічних теорій сновидінь відноситься підхід 3. Фрейда, який вважав, що сновидінням $є$ здійснене бажання, а його образи не $\epsilon$ безглуздими і хаотичними. Психологічна функція полягає у візуальній репрезентації суб'єктові прихованого змісту його несвідомого. Сенс сновидіння може бити зрозумілим тільки при символічному їх аналізі. Переробка інформації в сновидінні зводиться до 3 основних процесів:

1) згущування (концентрація) образів та їх накладення один на одне;

2) зміщення (заміщення), коли деякий прихований елемент проявля- 
ється у вигляді віддаленої асоціації, натяку; тому те, що знаходиться на периферії реально значимого переживання, в сновидінні може бути кульмінацією, центром; 3) символізування - процес трансформації думки в зорові образи.

Зв'язок символіки сновидінь і крос-культурних символів, що проявляються в релігії, міфах та ін., був досліджений К. Юнгом. Вчений зазначав, що символи продукуються людиною спонтанно і несвідомо. Сновидіння пов'язані з несвідомим та відображають колективне несвідоме, яке, діючи через сновидіння, використовує архетипічні, надособистісні, надкультурні символи.

Аналіз значення символіки сновидінь для життя і навіть здоров'я людини здійснив італійський психотерапевт, філософ і художник А. Менегетті, основоположник образно-символічної онтопсихології (психології буття). А. Менегетті запропонував авторське «раціональне» тлумачення образів сновидінь, назвавши свою систему «імагогікою», від «імаго» - образ об'єкту; образ суб'єктивного відношення до об'єкту. Термін імаго введений К. Юнгом і прийнятий у психоаналізі. Імагогіка, як зауважує дослідник - це свідомий і добровільний досвід прочитання активних образів, що відображають цілісність індивідуального існування на свідомому і несвідомому рівнях. Образи сну, на думку А. Менегетті, це вроджена «система саморегуляції» людського організму. У своїй книзі «Світ образів» вчений пише, що сновидіння реєструють реальний стан речей для суб'єкта. Фактаж денних подій вплітається у сценарій сновидіння. Необхідно звертати увагу на сни, бо вони надають критерій щоденних подій. Несвідоме, на думку А. Менегетті, є основою порядку, завдяки якому суб'єкт набуває реальності.

Аналіз наукової літератури та емпрічного матеріалу, отриманого в процесі психоаналізу матеріалу груп АСПП, дозволяє стверджувати, що діалогічна взаємодія психолога з респондентом задає можливості проникнення в смислові параметри несвідомого за умов наявності посередника, тобто візуалізованого репрезентанта. Останній перетворюється в посередника у процесі його «оживлення» в діалогічній взаємодії. Таким чином, матеріалізована репрезентація в іiї спонтанній невимушеності та індивідуальній непередбачуваності сприяє подоланню бар'єрів, створюваних відмінностями двох сфер (свідоме-не- 
свідоме), що відкриває перспективи пізнання несвідомого за участю свідомості, тобто «за законами твердого світу».

Таким чином, розглянуті вище підходи мають загальні теоретико-методологічні витоки, які їх поєднують. Проте, вони відрізняються фокусом дослідницького інтересу, глибиною і націленістю аналізу.

У результаті систематизації наукової літератури, важливим є уточнення понять «візуальний» та «візуалізований», так як вони мають певні відмінності у їх розумінні. Візуальне - це будь-що, яке виражене в зоровій формі представлення, а візуалізованим є зорове представлення, отримане в результаті творчої діяльності. Наприклад, символ Венери, знайомий людям до появи астрономії, є візуальним образом. Проте, символ Венери як елементу геліоцентричної моделі $є$ візуалізованим, бо він виник в результаті наукових досліджень. Специфікою візуальних представлень $є$ те, що якщо за основу образу сприйняття слугують відчуття, то в основі візуалізованого образу лежить ідея. Візуалізовані представлення потрібні для того, щоб виразити смисл у зрозумілому, доступному для сприйняття вигляді.

Отже, ми дотримуємось ідеї про те, що візуалізоване представлення відрізняється від звичайного зорового образу тим, що в його основі лежить абстрактно-логічне знання, яке виражає певну ідею, яку суб'єкт пізнання вважає головною, істотною, такою, яка відображає зміст. Можна сказати, що будь-яке візуалізоване представлення $є$ візуальним, але не кожне візуальне $\epsilon$ візуалізованим представленням.

Пізнання психічного як функціональної системи породжує необхідність перекодування у сферу візуалізованої реальності, доступної пізнанню за законами свідомої сфери. Спонтанна активність суб'єкта $\epsilon$ необхідною передумовою непрямолінійного перекодування неусвідомлюваних сенсів системної структури психічного у візуалізованих формах твердого світу, що відкриває перспективи для його вивчення за участю «свідомості» у дискретному світі. Здійснивши аналіз наукових джерел, ми дійшли до висновку, що візуальна репрезентація поділяється на: візуальну репрезентацію та візуалізовану.

\section{7. Перинатальна символіка у візуалізованій репрезентації}

Досліджуючи проблему перинатальної символіки у візуалізованій репрезентації майбутнього психолога важливо враховувати особли- 
вості характеристика рхетипу. Архетип (від гр. archetipos - прототип) центральне поняття аналітичної психології, яке введене К. Юнгом. Терміну «архетип колективного несвідомого» К. Юнг надавав дефініцій неодноразово. Це було пов'язано із маловивченістю, нерозумінням і невірною його інтерпретацією у тогочасному науковому середовищі. Наведемо наступні формулювання, що визначають архетип як: образ: «форми і образи, колективні за своєю природою, зустрічаються практично по усій землі як складові елементи міфів і що $є$ в той же самий час автохтонними індивідуальними продуктами несвідомого походження», які «передаються не лише за допомогою традиції або міграції, але також за допомогою спадковості» [8, с. 87]; тенденцію: «архетип $є$ тенденцією до утворення уявлень, які можуть значно коливатися в деталях, не втрачаючи при цьому своєї базової схеми..., інстинктивним вектором, спрямованим трендом, таким самим, як імпульс у птахів вити гнізда» [6, с. 115]; структурну форму: «апріорні структурні форми», що упереджують свідомість і об'єктивуються на інстинктивному рівні, які «не повинні розумітися як річ в собі, але лише як форма речі, яка може бути сприйнята» [8, с. 45]; орган психіки: «архетипи $\epsilon$ щось на зразок органів дораціональної психіки. Це постійно успадковані, завжди однакові форми та ідеї, що позбавлені специфічного змісту. Специфічний зміст з'являється лише в індивідуальному житті, де індивідуалізований досвід потрапляє саме в ці форми» [9, с. 95].

Термін «перинатальна символіка» був введений Т. Яценко у сфері глибинної психології. В результаті, ми змогли побачити не лише полізначність символіки, а й те, що вона має здатність звужуватись і набувати відносної однозначності за рахунок поздовжнього аналізу матеріалу. Цьому сприяє комплекс тематичних психомалюнків. Адже, психіка $є$ системно впорядкована, а повздовжні лінії $є$ вираженням сутності та індивідуальної неповторності психіки кожної людини. Важливим фактором є підбір матеріалу для визначення природи символів, а його фактаж набирається у відповідності з принципом додатковості, так як обидві сфери свідоме/несвідоме, причетні до самопрезентації суб'єкта. 3 огляду на дієвість і результативність психокорекційного процесу ми спираємось на візуалізовані репрезентанти. В процесі діалогічної взаємодії розкриваються смислові і семантичні (змістові) параметри суб'єкта. 
Шляхом аналізу ми виокремили та систематизували перинатальні символи, які найбільш зустрічаються у візуаліалізованій репрезентації майбутнього психолога. Зокрема символіка: утроби, внутрішньоутробного розвитку, пологів, пуповини, існування у новому середовищі (1-2 тиждень після народження суб'єкта). Розглянемо їх детальніше.

У авторських та неавторських малюнках символіка утроби виражається через використання наступних символів: кімната, ящик, сундук, корабель, човен, кулька, яйце, піраміда, мушля, палатка, замок, печера та ін. Порівняльний аналіз символіки художніх полотен та психомалюнків дозволяє констатувати не тільки схожість зображень але й внутрішнього змісту образу. Яйце як символ цілісності, вміщує в себе усі можливості розвитку універсуму, символізує утробу, яка містить насіння творення, із якої з'явилися істоти; символізує початок життя, нащадків, повторне народження і нове життя, зародок явищ та проблем тощо. Психіка паралельно $з$ мотивами і необхідністю просоціальної адаптації постійно вирішує проблему звільнення від того психологічного навантаження, яке породжується введенням табу на кровозмішення. В зв'язку з цим для нас зрозумілими є мотиви художніх полотен, в яких так часто є присутнім мотив яйця, мушлі, акваріуму тощо.

Проведене нами дослідження емпіричного матеріалу доводить латентний, прихований зміст візуалізованої репрезентації, що дозволяє простежити ії вплив на психіку суб'єкта. Встановлено, що об'єктивність чинників спонтанної активності суб'єкта, пов'язана з фіксаціями домовного періоду та має здатність виявлятися на символічному рівні. Травма, небажання народження та інші внутрішньоутробні особливості неусвідомлювані суб'єктом об'єктивуються у вигляді перинатальної символіки. Встановлено, що слідові енграми перенатального періоду не піддаються вербалізації, проте зберігають імпульс прояву назовні із збереженням у репрезентанта смислових параметрів.

Візуалізований символ, у його метафоричності, допускає варіативність у відображенні психічної реальності, тому увага центрувалась на повздовжньому психоаналізі отриманого матеріалу, що виявляє інваріантність та ітеративність смислових чинників. Об'єктивність чинників мимовільної активності суб'єкта пов'язана з фіксаціями домовного періоду. Слідові енграми внутрішньоутробного стану не піддаються вербалізації, проте вони зберігають імпульс прояву назовні зі збере- 
женням у репрезентанта смислових параметрів. Саме таке розуміння перспектив пізнання перинатальної символіки і спонукало дослідну ініціативу здійснення діалогічного психоаналізу процесу репрезентації майбутніх психологів.

Варіативність візуалізації проблем «утробності» архетипно презентують наступні зображення: пуповин, спіралеподібного розвитку зародків та ін. Пізнання майбутнім фахівцем-психологом власних неусвідомлюваних тенденцій відкриває йому перспективи особистісної гармонізації, набуття психологічної рівноваги та глибинно-психологічної компетентності.

\section{8. Висновки}

Отриманий в результаті проведеного дослідження матеріал прояснює вплив перинатального періоду розвитку психіки суб'єкта на спрямованість мимовільних побуджень до візуалізації. Підсумкові інтерпретації емпіричного матеріалу повинні охоплювати як опредметнені візуалізації (репрезентанти) суб'єкта, так і результати вербально-діалогічної взаємодії (психолог-респондент).

Дослідження відповідає методологічним основам психодинамічної теорії, в іiі орієнтованості на цілісність психіки (свідоме/несвідоме), що ставить певні вимоги до дослідної процедури, зокрема, врахування мови цих сфер, відповідно - словесна і образна. Додатковим аргументом використання у дослідженні візуалізованих репрезентантів $є$ необхідність віднайти способи дотичності до перинатальних слідів (що зберігаються у відповідних енергетичних осередках), які обумовлені чинниками, що не існували для індивіда у вербальному просторі. Використання авторського малюнку, а особливо репродукцій художніх полотен, було також наближеним до системності психічного, його «поздовжньо»-логічної впорядкованості. Вказані передумови дослідження дали змогу виявити наступне: перинатальна символіка піддається візуалізації у дітородно-метафоричних формах, логічні зв'язки в матеріалі легко виявляються завдяки наявності внутрішнього імпліцитного порядку та інтенціональності, що є характерною для архетипності символіки.

Візуалізований символ, у його метафоричності, допускає варіативність у відображенні психічної реальності, тому увага центрувалась на повздовжньому психоаналізі отриманого матеріалу, що виявляє інварі- 
антність та ітеративністьсмислових чинників. Доводиться, що об'єктивність чинників мимовільної активності суб'єкта пов'язана з фіксаціями домовного періоду. Слідові енграми того періоду не піддаються вербалізації, проте вони зберігають імпульс прояву назовні зі збереженням у репрезентанта смислових параметрів. Саме таке розуміння перспектив пізнання перинатальної символіки і спонукало дослідну ініціативу здійснення діалогічного психоаналізу процесу самопрезентацій майбутніх психологів.

У статті використано термін візуалізована (опредметнена) репрезентація суб'єкта, яка завдяки спонтанності поведінки сприяє істотному узагальненню перинатальних фіксацій (котрих не торкається побутова свідомість, що навантажена оцінними судженнями). Останнє передбачає введення спеціальних принципів, які включають - безоцінність, відсутність критики та прийняття людини такою, якою вона є та інше. Сам же по собі процес репрезентації особи візуалізованими засобами $\epsilon$ достовірною одиницею наукового аналізу психіки, як такої, що «себев-самій-собі ілюструє» шляхом опредметнення ідеальних реальностей.

Дослідження враховувало й те, що тенденції несвідомого у взаємодії зі свідомим є латентними, тому виявлення смислових параметрів репрезентантів потребувало діалогічної взаємодії психолога 3 піддослідним. Другий розділ дисертації науково узагальнює численні акти візуалізованоїсамопрезентації суб'єкта, зокрема шляхом психоаналізу авторських тематичних малюнків.

У розкритті даної проблеми ми спирались на архетипність образів перинатального періоду. Встановлено, що архетип має пряме відношення до символу як специфічного вираження витісненого й неусвідомлюваного змісту. Психодинамічна парадигма (Т. Яценко) стверджує, що архетип має дотичність до усіх підструктур психіки, зокрема, як до свідомого, так і несвідомого (включаючи систему психологічних захистів, особливо в базальній їх формі вияву). Архетип відіграє провідну роль в об'єктивуванні найбільш утаємничених осередків психіки.

Перинатальний період, як доводить аналіз емпірики, відіграє провідну роль у виникненні деструкцій поведінки суб'єкта, що є вкрай небажаним для майбутнього психолога, у фахові обов'язки якого входить адекватне відображення ситуації «тут і зараз», що задає результативність взаємодії з іншою людиною. 
Варіації візуалізації проблем «утробності» архетипно презентують: пуповини, спіралеподібний розвиток зародка та ін. Пізнання майбутнім фахівцем-психологом власних неусвідомлюваних тенденцій відкриває йому перспективи особистісної гармонізації, набуття психологічної рівноваги та глибинно-психологічної компетентності.

Перинатальні чинники не є нейтральними для подальшого життя особи через їхній вплив на формування негативних мотивів, що знаходять вияв у тенденціях до: «імпотенції психіки», «психологічної смерті», «психологічної самодепривації». Все це обумовлює необхідність особистісної психокорекції майбутнього психолога на упередження деструкцій професійної діяльності фахівця та дисфункцій у ставленні до інших людей.

Сказане вище ставить перед нами додаткові задачі та окреслює перспективи подальшого дослідження особливостей «захисного» синтезу смислових параметрів детермінант перинатального періоду в просоціально-професійну канву життя дорослої людини.

\section{Список літератури:}

1. Вартофский М. Модели. Репрезентация и научноепонимание / М. Вартофский. - М.: Прогресс, 1988. - 508 с.

2. Мещеряков Б.Г., Зинченко В.П. Большой психологический словарь / Б.Г. Мещеряков, В.П. Зинченко. - М.: Ольма-Пресс, 2004. - 672 с.

3. Петровский А.В. Краткий психологический словарь / А.В. Петровский. - М.: Политиздат, 1985. - 431 с.

4. Розенталь М. Краткий философский словарь / М. Розенталь. М.: Политиздат, 1954. - 704 с.

5. Малви Л. Визуальное удовольствие и нарративный кинематогроф / Л. Малви // Научный журнал «Антология гендорной теории». 2000. - С. 280-296.

6. Холл Дж. Юнгианское толкование сновидений / Дж. Холл. М.: Когито-Центр, 1996. - 168 с.

7. Шпиц Р. Психоанализ раннего детского возраста / Р. Шпиц. М.: Прогресс, 2001. - 240 с.

8. Юнг К.Г. Архетип и символ / К.Г. Юнг. - М.: Ренессанс, 1991. - 210 с.

9. Юнг К.Г. Душа и миф: шесть архетипов / К.Г. Юнг. - К.: Государственная библиотека Украины для молодежи, 1996. - 384 с.

10. Яценко Т.С. Малюнок у психокорекційній роботі психолога-практика (на матеріалі психоаналізу комплексу тематичних малюнків) / Т.С. Яценко. Черкаси: Арт-Брама, 2003. - 216 с. 


\section{References:}

1. Vartofskiy M. (1990). Modeli. Reprezentatsiya i nauchnoe ponimanie [Representation and scientific understanding]. Moscow: Progress. (in Russian)

2. Meshcheryakov B.G., Zinchenko VP. (ed.) (2004). Bol'shoy psikhologicheskiy slovar' [Great psychological dictionary]. Moscow: Olma-Press. (in Russian)

3. Petrovskiy A.V. (ed.) (1985). Kratkiy psikhologicheskiy slovar' [Brief psychological dictionary]. Moscow: Political Publishing House. (in Russian)

4. Rozental' M. (ed.) (1954). Kratkiy filosofskim slovar' [Brief Philosophical Dictionary]. Moscow: State Publishing House of Political Literature. (in Russian)

5. Malvi L. (2000). Vizual'noe udovol'stvie i narrativnyy kinematogrof [Visual pleasure and narrative kinematogrof]. Minsk: Propylaea. (in Russian)

6. Kholl Dzh. (1996). Yungianskoe tolkovanie snovideniy. Prakticheskoe rukovodstvo [Brief Philosophical Dictionary]. Moscow: Kogito Center. (in Russian)

7. Shpits R. (2001). Psikhoanaliz rannego detskogo vozrasta [Psychoanalysis of early childhood]. Moscow: Progress. (in Russian)

8. Yung K.G. (1991). Arkhetip i simvol [Archetype and symbol]. Moscow: Renaissance. (in Russian)

9. Yung K.G. (1996). Dusha i mif: shest' arkhetipov [Soul and myth: six archetypes]. Kyiv: State Library of Ukraine for Youth. (in Russian)

10. Yatsenko T.S. (2003). Jacenko T.S. Maljunok u psykhokorekcijnij roboti psykhologha-praktyka (na materiali psykhoanalizu kompleksu tematychnykh maljunkiv). [Picture at the psycho-correctional psychologist-psychologistpractitioner (on the basis of psychoanalysis to a complex of thematic malyunks)]. Cherkasy: Art Brahma. (in Ukrainian) 